\title{
IMPLIKASI UU NOMOR 6 TAHUN 2014 TENTANG DESA TERHADAP KEWENANGAN DESA
}

\author{
Kushandajani \\ Ilmu Pemerintahan Fakultas Ilmu Sosial dan Ilmu Politik Universitas Diponegoro \\ Email : ningpemfisip_undip@yahoo.co.id
}

\begin{abstract}
The main problem in this study was how the social significance of the existence of Desa autonomy regulation through the Law No. 6 of 2014. The existence of new regulation must be influence to desa's order, especially in local authority, Because of the local authority is the most important thing in local organization like Desa.The specific question tried to be answered in this study whether the Law could serve, integrate, and organize the local authority in Desa. The result of this research indicate three points. First, local authority existing that called "hak asal usul desa" coexist with local community and desa government. Second, the field of local authority as organization the governance of desa, implementation of the building of desa, and commmunity development will blossom out in the future depend on the needs of local community.Finally, design of local authority based on the Law No. 6 of 2014 can integrate and organize the local authority, if the national government still commit and consist to recognize the local authority whatever Desa has.
\end{abstract}

Kata kunci: local authority, local community, state law, recognition.

\begin{abstract}
Abstrak
Masalah utama dalam studi ini adalah bagaimana implikasi berlakunya UU No. 6 Tahun 2014 tentang Desa terhadap kewenangan desa. Kewenangan desa yang dimaksud adalah kewenangan desa yang berasal dari hak asal usul dan kewenangan lokal berskala desa, karena kedua bentuk kewenangan desa tersebutlah yang merupakan ruh otonomi desa. Hasil riset menunjukkan bahwa desa tidak bisa diperlakukan sama sebagaimana memperlakukan daerah kabupaten, karena hakekat otonomi desa berbeda dengan otonomi daerah. Kabupaten dibentuk sebagai pelaksana desentralisasi, yang melaksanakan sebagian kewenangan yang diberikan oleh Pusat. Desa berbeda, karena memiliki kewenangan yang berasal dari hak asal usul, bukan pemberian dari pusat. Otonomi desa sudah ada jauh sebelum republik ini berdiri, dan meski didesain ulang berkali-kali melalui kebijakan pusat tentang desa , namun otonomi desa tetep eksis, salah satunya adalah dengan keberadaan kewenangan hak asal usul yang melekat pada status sosial kepala desa dan pamong desa , apapun nama dan penyebutannya, serta tercermin dari perilaku masyarakat desa yang menjunjung tinggi kehidupan sosial budayanya.Pada akhirnya desain tentang kewenangan desa diajukan sebagai bagian dari solusi, yang mencoba mewadahi dua konstruksi tentang kewenangan desa, dimana kewenangan desa eksisting masuk dalam “wadah” yang dikonstruksi UU No. 6 Tahun 2015 tentang Desa, namun dengan semangat diterapkannya taat azas yaitu azas rekognisi, dimana pemerintah pusat dan daerahmengakui apapun kewenangan yang saat ini dilaksanakan oleh desa.

Kata kunci: kewenangan desa, hukum negara, hak asal usul desa, kewenangan lokal berskala desa, asas rekognisi.
\end{abstract}

\section{A. Pendahuluan}

Desa, secara sosiologis maupun politis memiliki posisi yang sangat kuat. Dengan jumlah sekitar 73.000 (tujuh puluh tiga ribu) desa dan sekitar 8.000 (delapan ribu) 
kelurahan menunjukkan bahwa masyarakat Indonesia sebagian besar hidup di desa. Dengan demikian, posisi pemerintah desapun memiliki arti strategis, karena posisinya yang paling dekat dengan masyarakat.

Dalam sejarah pengaturan tentang desa yang mengatur secara khusus tentang desa dari masa setelah kemerdekaan sampai sekarang hanya terdiri dari tiga undang-undang, yaitu UU No. 19 Tahun 1965 tentang Desapraja, UU No. 5 Tahun 1979 Tentang Pemerintahan Desa, dan terakhir UU No. 6 Tahun 2014 tentang Desa. Selebihnya pengaturan tentang desa diatur menjadi satu dengan pengaturan tentang pemerintahan daerah, seperti UU No. 22 Tahun 1999 tentang Pemerintahan Daerah dan UU No. 32 Tahun 2004 tentang Pemerintahan Daerah, dimana di dalamnya memuat beberapa pasal yang menyangkut pemerintahan desa.

Konstruksi hukum yang ada pada UU No. 6 Tahun 2014 memuat sesuatu yang baru. Pertama, UU tentang desa ini lahir lahir lebih dahulu dibandingkan UU tentang pemerintahan daerah (UU No. 23 Tahun 2014 tentang Pemerintahan Daerah). Kedua, lahirnya UU tentang desa yang baru ini merefleksikan semangat dan penghargaan terhadap desa atau yang disebut dengan nama lain , yang diakui telah ada sebelum Negara Kesatuan Republik Indonesia terbentuk. Ketiga, keberagaman karakteristik dan jenis Desa, meskipun disadari bahwa dalam suatu negara kesatuan perlu terdapat homogenitas, tetapi Negara Kesatuan Republik Indonesia tetap memberikan pengakuan dan jaminan terhadap keberadaan kesatuan masyarakat hukum dan kesatuan masyarakat hukum adat beserta hak tradisionalnya. (UU No. 6 Tahun 2014, bagian Penjelasan).

Salah satu dimensi terpenting di desa adalah kewenangan yang dimiliki desa untuk mengelola pemerintahan. Pada saat berlakunya IGO dan IGOB, urusan rumah tangga desa dibatasi hanya mengurus urusan fisik saja seperti pemakaian dan pemeliharaan pekerjaan umum desa yang menyangkut jalan, jembatan, saluran air, rumah, tanah, lapangan, pasar dan tempat penyimpanan air. ( Inlandsch Gemeente Ordonnantie /IGO, ps. 7 dalam Surianingrat, 1986: 153).

Dalam UU No. 5 Tahun 1979 tentang Pemerintahan Desa, kewenangan desa tidak dijelaskan pada pasal tersendiri, tetapi melekat pada hak, wewenang dan kewajiban Kepala Desa. (UU No. 5 Tahun 1979, psl. 10) Kepala Desa menjalankan hak, wewenang, dan kewajiban pimpinan pemerintahan desa yaitu menyelenggarakan rumah tangganya sendiri dan merupakan penyelenggara dan penanggungjawab utama di bidang pemerintahan, pembangunan dan kemasyarakatan dalam rangka penyelenggaraan urusan pemerintahan desa, urusan pemerintahan umum termasuk pembinaan ketentraman dan ketertiban sesuai 
dengan peraturan perundang-undangan yang berlaku dan menumbuhkan serta mengembangkan jiwa gotong royong masyarakat sebagai seni utama pelaksanaan pemerintahan desa. Dengan demikian, kewenangan/urusan/fungsi desa meliputi kewenangan rumah tangga desa, kewenangan pemerintahan desa, dan kewenangan pemerintahan umum.

Adapun kewenangan desa di dalam UU No. 22/1999 diatur dalam pasal 99 mencakup: (a) kewenangan yang sudah ada berdasarkan hak asal usul Desa; (b) kewenangan yang oleh peraturan perundang-undangan yang berlaku belum dilaksanakan oleh Daerah dan Pemerintah; dan (c) tugas pembantuan dari Pemerintah, Pemerintah Propinsi, dan /atau Pemerintah Kabupaten.Dalam Undang - undang No. 32 Tahun 2004 disebutkan urusan pemerintahan yang menjadi kewenangan desa mencakup (1) urusan pemerintahan yang sudah ada berdasarkan hak asal usul desa, (2) urusan pemerintahan yang menjadi kewenangan kabupaten/kota yang diserahkan pengaturannya kepada desa, (3) tugas pembantuan dari Pemerintah, Pemerintah provinsi, dan atau pemerintah kabupaten/kota dan yang terakhir (4) urusan pemerintahan lainnya yang oleh peraturan perundangperundangan diserahkan kepada desa. Tugas pembantuan dari Pemerintah, Pemerintah Provinsi, dan/atau pemerintah Kabupaten/kota kepada desa disertai dengan pembiayaan, sarana dan prasarana, serta sumber daya manusia.

UU No. 6 Tahun 2014 tentang Desa mengkonstruksi kewenangan desa dalam pasal 18, yang meliputi kewenangan di bidang penyelenggaraan Pemerintahan Desa, pelaksanaan Pembangunan Desa, pembinaan kemasyarakatan Desa, dan pemberdayaan masyarakat Desa berdasarkan prakarsa masyarakat, hak asal usul, dan adat istiadat Desa. Adapun di pasal 19 Kewenangan Desa meliputi: a. kewenangan berdasarkan hak asal usul; b. kewenangan lokal berskala Desa; c. kewenangan yang ditugaskan oleh Pemerintah, Pemerintah Daerah Provinsi, atau Pemerintah Daerah Kabupaten/Kota; dan d. kewenangan lain yang ditugaskan oleh Pemerintah, Pemerintah Daerah Provinsi, atau Pemerintah Daerah Kabupaten/Kota sesuai dengan ketentuan peraturan perundang-undangan.

Berdasarkan latar belakang tersebut, dirumuskan permasalahan penelitian : Bagaimana implikasi UU No. 6 Tahun 2014 tentang Desa terhadap kewenangan desa ? Untuk menjawab pertanyaan tersebut tentu saja dilakukan identifikasi terhadap kewenangan desa yang saat ini dilaksanakan, dan menemukan desain kewenangan desa yang menghubungkan dua konstruksi, konstruksi negara melalui UU No. 6 Tahun 2014 tentang Desa dan konstruksi pemerintah dan masyarakat desa. 
Dalam perspektif teoritik, kajian terhadap otonomi desa biasanya berkaitan dengan bagaimana negara "memperlakukan” desa. Dilihat secara mendalam makna pengaturan sebagaimana tercantum dalam pasal 18 UUD 1945 berikut penjelasannya, maka dapat dikatakan bahwa esensi dari pasal tersebut mencerminkan pengakuan negara terhadap apa yang disebut “otonomi desa” dewasa ini. Lebih dari itu, dengan menyebutkan desa sebagai “susunan asli yang memiliki hak asal usul” , maka menurut UUD 1945 hanya desa yang dipastikan memiliki otonomi. (Kushandajani, 2008:32)

Otonomi desa juga terlihat di desa-desa di Jawa dimana berdasarkan adat istiadat penduduk desa berhak memilih kepala desanya sendiri dan menggantinya kalau perbuatan kepala desa tersebut tidak memuaskan masyarakat desa. (Tjiptoherijanto, 1983: 18) Sementara itu wewenang paling tinggi di desa adalah rapat desa, dimana semua orang dewasa dari masyarakat desa berhak untuk menghadiri rapat desa dan berbicara serta memberikan suara. (Hofsteede, 1971: 52)

Dengan demikian, otonomi desa adalah otonomi yang sudah ada sejak desa itu terbentuk. Otonomi desa berlandaskan adat, mencakup kehidupan lahir dan batin penduduk desa, dan tidak berasal dari pemberian pemerintah. (Surianingrat, 1980: 14) Otonomi desa berarti otonomi komunitas atau masyarakat setempat dalam mengorganisir diri mereka sendiri. Namun demikian, hakekat local autonomy berbeda dengan kedaulatan, karena local autonomy adalah otonomi masyarakat setempat yang menyangkut berbagai urusan pemerintahan yang bersifat lokalitas. (Hoessein, 2001: 38) Dengan demikian, desa lebih dipahami sebagai suatu daerah kesatuan hukum dimana bertempat tinggal suatu masyarakat yang berkuasa mengadakan pemerintahan sendiri. (Kartohadikoesoemo, 1965: 3) Lebih lanjut menurut Kartohadikoesoemo (1965:281) pengertian tentang kewenangan sesuatu daerah hukum yang dilukiskan dengan istilah asing "otonomi” - dalam bahasa Indonesia: hak untuk mengatur dan mengurus "rumah tangga” sendiri - dalam hukum adat sebenarnya tidak dikenal oleh bangsa Indonesia.Hukum adat yang mengatur segenap peri kehidupan rakyat di desa, tidak membeda-bedakan (memisahkan) peratuan-peraturan yang mengatur hubungan antara orang-orang sebagai manusia perseorangan dari peraturan-peraturan yang mengatur tatadesa sebagai daerah hukum, juga tidak dari peraturan-peraturan yang mengatur kepercayaan, cara orang berbakti kepada Tuhan dan kepada roh suci cikal bakal (“danyang” desa). Lebih lanjut disebutkan kekuasaan desa tidak saja berisi pemerintahan dalam arti kata yang sempit (bestuur), akan tetapi juga berisikan pemerintahan dalam arti 
kata yang lebih luas (regering), sebab desa juga berkuasa atas: pengadilan, perundangundangan (legislatif), kepolisian, dan juga pertahanan. (Kartohadikoesoemo, 1965: 135)

\section{B. Metode Penelitian}

Penelitian ini termasuk ke dalam socio-legal research, dimana penggunaan teori ilmu-ilmu sosial (termasuk di dalamnya sosiologi, ilmu politik, dan ekonomi) di dalam menerangkan masalah hukum mendapatkan tempatnya dalam socio-legal studies, atau sering pula disebut sebagai "studi tentang hukum dan institusi legal dari perspektif ilmu sosial”. (Hunt, 1993; Turkel, 1996; Luhmann, 1985). Pendekatan sosiologis terhadap hukum berarti, antara lain , suatu penyorotan terhadap konteks hukum dan prosesnya, karena Ilmu hukum dan ilmu-ilmu sosial mempunyai hubungan yang saling melengkapi dan saling mempengaruhi. (Warassih, 2005: 5)

Penelitian ini mengutamakan perspektif emic, artinya mementingkan pandangan informan, yakni bagaimana ia memandang dan menafsirkan dunia dari pendiriannya. (S. Nasution, 1996: 10) Dengan demikian hasil penelitian ini tidak dimaksudkan untuk mencari generalisasi yang luas, karena temuan bergantung pada interaksi antara peneliti dan subjek penelitian, dimana pelaku-pelaku mendapat tempat untuk memainkan peranannya. (Ashshofa, 2004: 21) Teknik pengumpulan data mengutamakan penggunaan data langsung (fist hand) yang diperoleh dari beberapa nara sumber melalui teknik wawancara mendalam (depth interview) dan diskusi kelompok terbatas(focussed group discussion/FGD).

Situs penelitian di tiga desa: (1) Desa Pekuncen, Kecamatan Jatilawang, Kabupaten Banyumas; (2) Desa Lerep, Kecamatan Ungaran Barat, Kabupaten Semarang, dan (3) Desa Trajumas, Kecamatan Kandangserang, Kabupaten Pekalongan. Alasan pemilihan ketiga desa tersebut karena masing-masing memiliki karakteristik yang berbeda. Pemilihan Desa Pekuncen didasarkan pada eksistensi komunitas Islam Kejawen Bonokeling atau biasa disebut ”Islam Blangkon”. (Widyandini, dkk, 2013), dan pada Oktober 2011 menjadi salah satu proyek percontohan desa adat di Indonesia (tribunjateng.com.banyumas, Accessed: 5 April 2014 , jam 13:24) Pemilihan Desa Lerep didasarkan pada pertimbangan desa asli yang mengalami perubahan dengan tumbuhnya perumahan-peperumahan baru dalam wilayahnya. Terakhir, penetapan Desa Trajumas karena desa tersebut merupakan desa hasil pemekaran yang terbentuk pada tahun 2009 melalui Peraturan Daerah Kabupaten Pekalongan No. 6 Tahun 2009 tentang Pembentukan Desa Trajumas dan Desa Karanggondang serta Penetapan 
Kembali Wilayah Kerja Desa Sukoharjo Kecamatan Kandangserang Kabupaten Pekalongan.

\section{Hasil Penelitian dan Pembahasan}

\section{Profil Desa Penelitian}

a. Desa Pekuncen, Kecamatan Ajibarang, Kabupaten Banyumas

Desa Pekuncen merupakan satu dari sebelas desa yang terdapat di Kecamatan Jatilawang, Kabupaten Banyumas. Desa ini memiliki luas wilayah 490 Ha yang terbagi menjadi 3 dusun, yaitu Dusun 1: Pekuncen Kulon/Pekuncen Ngisor; Dusun 2: Pekuncen Nggunung kadang disebut Dusun Kalilirip atau Dusun Kalisalak; Dusun 3: Pekuncen Wetan. Ketiga dusun tersebut terdiri dari 6 Rukun Warga (RW), dan 31 Rukun Tetangga (RT). Rata-rata penduduk Desa Pekuncen bermata pencaharian sebagai petani lahan persawahan tadah hujan dan perkebunan.

Mayoritas penduduk Desa Pekuncen berasal dari satu keturunan yang samayaitu Bonokeling, yang merupakan penganut Islam Blangkon atau yang lebih dikenal dengan istilah Islam Kejawen. Sebagai penganut Kejawen, masyarakat Bonokeling ini melaksanakan semua aktifitas ritual kepercayaan pada Situs Bonokeling yang terletak di permukiman Bonokeling. "Menungsa urip teng dunya niku nek mboten nyantri nggih nyandi" (Manusia hidup di dunia kalau tidak nyantri ya nyandi). Pernyataan ini berarti bahwa, manusia hidup di alam dunia ini terbagi menjadi dua, yaitu "nyantri” dan "nyandi". Nyantri adalah istilah untuk kelompok muslim dengan pengamalan Rukun Islamnya yang lima secara utuh atau Islam lima waktu. Sedangkan Nyandi adalah istilah untuk kelompok muslim yang pengamalan rukun Islamnya hanya tiga (syahadat, puasa dan zakat), tanpa melakukan haji dan shalat lima waktu. (Mulyareja dalam Ridwan, dkk, 2008 : 84)Komunitas Bonokeling mengucapkan dua kalimat syahadat pada saat mereka menikah secara resmi di Kantor Urusan Agama (KUA).

Menurut sejarah,sebagaimana dituturkan oleh ketua komunitas Bonokeling, Mbah Mitro (55), Bonokeling merupakan anak dari bangsawan Kadipaten Pasirluhur, bagian dari Kerajaan Padjajaran di Sunda, yang melarikan diri karena perkembangan Islam.Dia membangun pemukiman dan komunitas di Pekuncen, yang dikenal saat ini sebagai Anak Putu Bonokeling. Menurut Karsito (Carik, 35 tahun), Desa Pekuncen dan Desa Kedungwringin pada mulanya adalah satu. Hingga pada sekitar tahun 1917 kedua desa ini berpisah, dengan pembatas Sungai Tajum. Di sebelah Selatan Sungai Tajum adalah Desa Pekuncen dan Sebelah Utara Sungai Tajum adalah Desa 
Kedungwringin. Desa Pekuncen sebagian besar wilayahnya berupa pegunungan dengan tanah kering, sedangkan Desa Kedungwringin berupa dataran rendah dengan tanah yang relatif sangat subur (sehingga sebagian besar tanahnya untuk areal pesawahan).

\section{b. Desa Lerep, Kecamatan Ungaran Barat, Kabupaten Semarang}

Secara administratif letak geografis Desa Lerep dibatasi oleh 5 (lima) Desa/kelurahan pada sisi-sisinya. Di sisi barat, Wilayah Desa Lerep berbatasan dengan wilayah administrasi Desa Keji Kecamatan Ungaran Barat Kab. Semarang dan Desa Kalisidi Kecamatan Ungaran Barat Kab. Semarang, di sisi selatan berbatasan dengan Wilayah Perhutani (Hutan Lindung Lereng Gunung Ungaran) dan Desa Nyatnyono Kecamatan Ungaran Barat Kab. Semarang, sementara di sisi timur wilayah Desa Lerep berbatasan dengan Wilayah Desa Nyatnyono Kecamatan Ungaran Barat Kab. Semarang dan Kelurahan Ungaran Kecamatan Ungaran Barat Kab. Semarang dan sebelah utara berbatasan dengan Kelurahan Bandarjo Kecamatan Ungaran Barat Kab. Semarang dan Kelurahan Sumur Rejo Kecamatan Gunungpati Kota Semarang.

Luas Desa Lerep keseluruhan adalah 682,32 hektar atau sekitar 18,96\% dari luas Kecamatan Ungaran Barat (3.596,05 ha) atau 0,72\% dari luas Kabupaten Semarang (95.020,67 ha). Kewilayahan Desa Lerep dibagi dalam delapan dusun. Pertama, Dusun Indrokilo meliputi RW 1 yang terdiri dari 4 RT dengan jumlah 162 Kepala Keluarga (KK). Kedua, Dusun Lerep meliputi RW II yang terdiri dari 8 RT dengan jumlah 301 KK dan RW III yang terdiri dari 7 RT dengan jumlah 261 KK. Ketiga, Dusun Soka meliputi RW IV yang terdiri dari 8 RT dengan jumlah 360 KK. Keempat, Dusun Tegalrejo meliputi RW V yang terdiri dari 3 RT dengan jumlah 145 KK. Kelima, Dusun Lorog meliputi RW VI yang terdiri dari 5 RT dengan jumlah 195 KK. Keenam, Dusun Karangbolo meliputi RW VII yang terdiri dari 3 RT dengan jumlah 147 KK. Ketujuh, Dusun Kretek meliputi RW VIII yang terdiri dari 8 RT dengan 368 KK. Kedelapan, Dusun Mapagan meliputi RW IX yang terdiri dari 12 RT dengan 359 KK dan RW X yang terdiri dari 7 RT dengan 235 KK.Data Monografi Desa Lerepberjumlah10.195jiwadengan 2.555KK, denganrata-rata kepadatan penduduk

Desa Lerep tahun 2014sebesar 1.494 jiwa $/ \mathrm{km}^{2}$. Hampir separuh dari jumlah penduduk belum dan atau tidak bekerja. 
Dimensi organisasi pemerintah desa, Desa Lerep masih mengacu pada peraturan Desa Lerep No. 1 Tahun 2002 tentang Susunan Organisasi dan Tata Kerja Pemerintah Desa yang merupakan tindak lanjut dari Peraturan Daerah Kabupaten Semarang No. 7 Tahun 2000 tentang Pedoman Susunan Organisasi dan Tata Kerja Pemerintah Desa, yang terdiri seorang Kepala Desa, dibantu seorang Sekretaris Desa (, delapan Kepala dusun, tiga Kepala Urusan, dua Kepala Seksi, empat Unsur Staf Teknis.

\section{c. Desa Trajumas, Kecamatan Kandangserang, Kabupaten Pekalongan}

Desa Trajumas merupakan desa bentukan baru yang ditetapkan dengan Peraturan Daerah Kabupaten Pekalongan No. 6 Tahun 2009 tanggal 27 April 2009 tentang Penetapan Desa Trajumas dan Desa Karanggondang serta Penetapan Kembali Wilayah Kerja Desa Sukoharjo Kecamatan Kandangserang Kabupaten Pekalongan yang mulai diberlakukan sejak tanggal 3 Agustus 2010. Pemberlakuan Perda inilah yang ditetapkan sebagai hari lahir Desa Trajumas.

Legenda masa penjajahan menyebutkan awalnya ada 3 (tiga) desa yang jaraknya berdekatan akan tetapi terpisah dalam 3 'grumbul' (kelompok) permukiman. Tiga desa tersebut adalah Desa Sicengis, Desa Sigugur, dan Desa Gunung Langu. Ketiga desa ini-sebagaimana desa-desa lainnya — harus mengirimkan upeti dan hasil panen kepada penjajah Belanda, yang bagi warga masyarakat dirasakan sangat berat. Melihat kondisi tersebut, para tetua desa sepakat untuk menggabung tiga desa tersebut menjadi satu desa dengan nama SUKOHARJO.

Setelah lebih dari 60 tahun jumlah penduduk di desa asal semakin besar dan kebutuhan masyarakat terhadap pelayanan dasar semakin meningkat. Akan tetapi peningkatan kebutuhan atas akses terhadap pelayanan dasar ini tidak diikuti dengan peningkatan sarana prasarana dasar. Di sisi lain, mulai tahun 2006 masing-masing desa di Kabupaten Pekalongan setiap tahun mendapatkan Alokasi Dana Desa (ADD), tidak terkecuali Desa Sukoharjo. Dana ini merupakan sumber dana utama untuk membangun sarana prasarana yang ada di desa. Meskipun penetapan jumlah pagu anggaran tiap-tiap desa berdasarkan pada alokasi tetap dan alokasi proporsional, akan tetapi jumlah yang diterima Desa Sukoharjo tidak cukup untuk membangun sarana prasarana dasar khususnya jalan desa. Pemikiran tokoh-tokoh masyarakat desa juga semakin terbuka ketika PNPM Mandiri Perdesaan hadir tahun 2010, dimana program ini juga memberikan kesempatan kepada masing-masing desa untuk berkompetisi mendapatkan alokasi Bantuan Langsung Masyarakat (BLM) dengan jumlah anggaran yang jauh lebih besar dari alokasi ADD. 
Melihat kondisi masalah dan potensi sumber dana pembangunan dari ADD yang pembagiannya per desa, tahun 2007 masyarakat mulai mengadakan serangkaian rembug untuk memekarkan desa kembali menjadi 3 desa sebagaimana sebelumnya, akan tetapi dengan nama yang berbeda yaitu: Desa Trajumas, Desa Karanggondang, dan Desa Sukoharjo sebagai desa induk/asal. Inisiasi pemekaran desa kembali ini diprakarsai oleh Bapak Bambang Santosa yang saat itu merupakan ketua Badan Permusyawaratan Desa (BPD) Desa Sukoharjo. Gagasan pemekaran disampaikan kepada Pemerintah Kecamatan dan diteruskan ke tingkat kabupaten. Di tingkat kabupaten dilakukan kajian sesuai dengan aturan-atura yang berlaku saat itu Dengan memperhatikan syarat-syarat yang tertuang dalam Peraturan Menteri Dalam Negeri No. 28 Tahun 2006 tentang Pembentukan, Penghapusan, Penggabungan Desa dan Perubahan Status Desa Menjadi Kelurahan akhirnya gagasan pemekaran ini disetujui Bupati dan DPRD saat itu.

Dengan memperhatikan persyaratan tersebut, maka Desa Sukoharjo akhirnya disetujui dipecah menjadi 3 (tiga) Desa yaitu Desa Trajumas, Desa Karanggondang dan Desa Sukoharjo.Sebagai payung hukum kemudian diterbitkan Peraturan Daerah Kabupaten Pekalongan No. 6 Tahun 2009 tentang Pembentukan Desa Trajumas dan Desa Karanggondang serta Penetapan Kembali Wilayah Kerja Desa Sukoharjo Kecamatan Kandangserang Kabupaten Pekalongan.

Desa terdiri dari tujuh dusun yaitu Mekarmas, Trajumas, Karangwringin, Purwosari, Wanasari, Purwodadi, dan Purwomas. Sebagai desa yang relatif baru, desa Trajumas merupakan wilayah yang sulit dijangkau. Kondisi sarana prasarana jalan menuju wilayah desa Trajumas dari Desa Sukoharjo kondisinya sangat memprihatinkan bahkan membahayakan. Saat ini hanya ada satu jenis sarana transportasi yang oleh masyarakat Pekalongan disebut 'doplak'—yaitu mobil pickup — sebagai satu-satunya sarana transportasi masyarakat. Kendaraan inilah yang menjadi satu-satunya pilihan warga untuk keperluan belanja ke pasar Kajen ataupun kegiatan-kegiatan sosial lainnya.

\section{Kewenangan Desa Eksisting}

\section{a. Desa Pekuncen, Kecamatan Jatilawang, Kabupaten Banyumas}

Komunitas Bonokeling tinggal menyebar, hampir semua desa di Kecamatan Jatilawang ada keturunan Bonokeling, bahkan sampai ke Kabupaten Cilacap, namun yang inti tinggal mengelompok di Dusun Pekuncen, dekat makam Mbah 
Bonokeling. Dengan demikian permukiman Bonokeling terpusat di Dusun I Grumbul/Dusun Pekuncen. Permukiman ini ditandai dengan permukiman yang dibatasi oleh pagar bambu keliling dengan batas sebelah Barat adalah jalan ritual yang bernama Lurung. Permukiman ini memiliki 1 Kuncen dan 5 Bedogol (pemimpin keluarga) dengan rumah adat mereka yang bernama Kongsen. Adapun komunitas Bonokeling yang berada di Dusun II Kalisalak hanya memiliki 1 Kuncen saja.

Di Desa Kedungwringin, Tinggarjaya, Gunungwetan ada anak anak putu Bonokeling, ditandai dengan rumah ibadah pasemuan-nya juga. Sekitar Juni ada ritual besar unggah-unggah, ada sekitar 3000 orang Bonokeling yang melaksanakan , karena semua turunan datang, bahkan yang dari Cilacap yang datang dengan berjalan kaki. Sebagai penganut Kejawen, masyarakat Bonokeling ini memiliki banyak ritual kepercayaan, baik yang terjadwal maupun yang tidak terjadwal. Ritual yang terjadwal antara lain Unggah-Unggahan, Perlon Turunan, Perlon Rikat, SedekahBumi, dan Kupatan Senin Paing. Sedangkan ritual yang tidak terjadwalcontohnya upacara Mlebu, Puput Puser, Nikah. Pada intinya semua ritual ini bertujuan untuk menghormati leluhurnya yaitu Bonokeling. Masyarakat Untuk melaksanakan semua aktifitas ritual kepercayaan tersebut, masyarakat Bonokeling melakukannya pada Situs Bonokeling yang terletak di permukiman Bonokeling.

Menurut Mbah Mitro (ketua kelompok masyarakat Bonokeling), masyarakat Bonokeling juga melakukan puasa dan zakat seperti umumnya Islam taat (penyebutan untuk Islam santri), hanya saja pada pelaksanaannya ada perbedaannya. Jika puasa Islam santri diakhiri pada saat adzan mahrib berkumandang, namun puasa masyarakat Bonokeling diakhiri pada saat matahari mulai terbenam dan perut sudah terasa sakit maka saat itulah sudah boleh berbuka puasa. Adapun untuk zakat masyarakat Bonokeling diserahkan kepada Kayim (Kaur Kesra) sebesar Rp 3.000,00 - Rp 10.000,00 per kepala keluarga. Zakat yang terkumpul disalurkan kepada orang miskin yang juga penganut Kejawen. Adapun zakatnya Islam santri dikumpulkan kepada ketua Ta'mir Masjid Al-Islah Desa Pekuncen dengan ketentuan 2,5 kg beras per orang.

Fungsi sosial seperti kelahiran anak atau kematian warga Desa Pekuncen dikelolaoleh dua pihak yaitu untuk warga Islam Taat dan Islam Kejawen Bonokeling. Apabila ada warga golongan Islam Taat yang meninggal maka yang mengurus adalah sesama warga Islam Taat dengan dipimpin oleh Pak Kyai. Islam Taat ini melaksanakan Rukun Islam sebagaimana mestinya, salah satunya dengan shalat di 
mushola desa (yang beraliran NU). Sedangkan apabila ada warga Bonokeling yang meninggal maka yang mengurus adalah Tundagan (petugas pengurus jenasah) dimana jenasah ikut Bedogol tertentu. Misal warga tersebut ikut garis keturunan Bedogol Wiryatpada, maka yang mengurus jenasahnya adalah Tundagan Bedogol Wiryatpada (tiap Bedogol memiliki petugas Tundagan). Selanjutnya yang mendoakan adalah Kayim.

Proses kelahiran warga Desa Pekuncen telah dibantu oleh Bidan Desa (ada 2 orang) dengan bantuan dukun bayi (ada 3 orang). Proses pembuatan akta kelahiran antara warga Islam Taat dengan Islam Kejawen Bonokeling adalah sama, tidak ada perbedaan. Orang tua mengurus langsung ke Balai Desa, lalu oleh perangkat dibantu pengurusannya ke Pemda. Warga terima surat/akta yang sudah jadi.

Pemerintah Desa Pekuncen dalam memperlakukan warga Bonokeling adalah sama dengan warga desa (Islam Taat) lainnya. Begitu juga dengan pelayanan administrasi pun perlakuannya dan biaya yang sama (biaya pembuatan surat-surat ditetapkan dalam Peraturan Desa tentang Pungutan Desa). Kecuali untuk perangkat desa dan warga tidak mampu mereka dibebaskan dari biaya-biaya administrasi.

Bahkan Pemerintah Desa memberikan dukungan pada apa yang dilakukan komunitas Bonokeling dalam mempertahankan tradisinya. Diantaranya adalah dengan memberikan ruang yang sangat luas bagi komunitas Bonokeling untuk senantiasa melaksanakan berbagai ritual keyakinannya serta menjalin kerjasama dengan sesama komunitas Bonokeling di Cilacap (Adiraja, Daun Lumbung, Kalikudi, Pesanggrahan). Kerjasama denga pihak luar seperti Dinas Perdagangan, Industri dan Koperasi (Disperindakop) Kabupaten Banyumas dengan menyediakan 5 alat tenun dan pelatihan membuat kain tenun khas Bonokeling, Dinas Pariwisata dan Budaya (Disparbud) dengan pembentukan Kelompok Masyarakat (Pokmas) Pelestarian Adat Bonokeling. Pemerintah Desa juga mendorong komunitas Bonokeling untuk mengembalikan bentuk rumah Kongsen Bedogol Wiryatpada dan Kongsen Kuncen Kartasari (atap Srotong) ke bentuk semula (atap Tikelan-Joglo tapi kecil dan tidak terlalu tinggi), dan rehab rumah Kongsen Padawijaya dan membuat rumah tamu untuk pengunjung. Ruang yang luas juga diberikan oleh Pemerintah Desa Pekuncen untuk berlatih kesenian khas Bonokeling yaitu Rengkong (kesenian menggoyang-goyangkan tumpukan jerami yang dipanggul di pundak hingga menghasilkan suara-suara yang indah). Selain itu, komunitas Bonokeling juga membentuk Pokmas Bonokeling dengan struktur organisasi sebagai berikut: Ketua adalah Sumitro, mantan anggota 
BPD Desa Pekuncen; Bendahara adalah Warsito (Kadus III); Sekretaris adalah Sono (Guru).

Melihat struktur di atas, terlihat bahwa baik pemerintah desa dan komunitas Bonokeling pada dasarnya adalah bersumber pada satu keturunan, sehingga dua struktur (pemerintah desa dan komunitas Bonokeling) saling berkelindan, dan berujung pada penguaatan satu sama lain. Tradisi yang dilakukan komunitas Bonokeling secara tidak langsung mendukung fungsi Pemerintah Desa Pekuncen, tidak saja dalam bidang sosial, kebudayaan, pariwisata, namun jug, pertanian, kesejahteraan masyarakat, pemberdayaan masyarakat, pendidikan, dan keamanan.

Di bidang pendidikan, Komunitas Bonokeling memiliki Pendidikan Anak Usia dibawah Lima Tahun (PAUD). Bangunan terletak di bekas warung milik Bapak Maryoto, salah seorang warga Bonokeling, dengan guru juga dari warga Bonokeling. Untuk sekolah TK warga Bonokeling bersekolah di TK Pertiwi Desa Pekuncen sedangkan untuk SD warga Bonokeling belajar di SD Negeri Desa Pekuncen dan membaur dengan warga Desa Pekuncen lainnya.

Oleh karena sekitar 90 \% penduduk Desa Pekuncen adalah keturunan langsung maupun tidak langsung dari Bonokeling, maka terjadi hubungan yang harmoni antara komunitas dengan pemerintah desa. Keberadaan komunitas selalu menjadi bagian penting dari pemerintahan desa, terbukti dari kegiatan komunitas yang selalu didukung, tidak pernah dibatasi, oleh pemerintah desa. Keberadaan Kuncen (juru kunci komunitas) dihormati oleh pemerintah desa, sebagaimana komunitas juga menghargai Lurah (kepala desa) dengan sebutan kyai lurah. Kepala desa berperan penting juga dalam kegiatan-kegiatan ritual komunitas, terutama saat bulan puasa.

Secara umum dalam kehidupan sehari-hari tidak ada masalah antar warga, baik komunitas Bonokeling Pekuncen dengan Bonokeling Kalisalak maupun Bonokeling dengan warga Islam Taat. Saat ada yang mbarang gawe (pesta), mereka semua saling menghadiri. Namun saat upacara ritual seperti Unggah-Unggahan dan Kurban, maka komunitas Bonokeling Kalisalak tidak akan datang ke Pekuncen (walaupun komunitas Bonokeling dari Cilacap juga datang ke Pekuncen). Begitu juga sebaliknya, komunitas Bonokeling Pekuncen juga tidak akan menghadiri ritual yang dilaksanakan oleh Bonokeling Kalisalak (Pekuncen Gunung). Warga Bonokeling Pekuncen juga saling pamali menikah dengan warga Bonokeling Kalisalak, namun boleh menikah dengan warga Bonokeling dari Cilacap. Hal ini karena mereka menaati aturan adat komunitas Bonokeling Pekuncen yang melarang menikah dengan komunitas 
Bonokeling Kalisalak. Dengan demikian berlakunya hukum adat pada komunitas Bonokeling berbanding lurus dengan ketaatan pada hukum negara, di satu sisi taat pada hukum adat komunitas, di sisi lain sangat menghormati pemerintah desa sebagai representasi negara dengan cara menghormati Kyai Lurah.

Para pemimpin adat (Ketua Pokmas, Kuncen, Bedogol) tidak memberikan pelayanan yang bersifat administrasi. Dengan demikian warga komunitas Bonokeling yang membutuhkan pelayanan administrasi langsung mengurusnya ke balai dusun (kantor pemerintah desa). Kuncen terbatas hanya melayani pelayanan yang bersifat religi, misalnya warga yang ingin ziarah ke makam Bonokeling sedangkan Ketua Pokmas sebagai humas bagi pengunjung/peneliti yang ingin tahu tentang Bonokeling.

Lurah memperoleh bengkok seluas 2500 ubin (catatan: 1 ubin sama dengan 14 $\mathrm{m} 2$ ), ditambah tunjangan dari pemerintah yang berasal dari bagian Dana Alokasi Umum Desa (ADD). Adapun Sekretaris Desa mendapat bengkok seluas 120 ubin dan tunjangan pemerintah sebagai Pegawai Negeri Sipil (PNS), sedangkan perangkat lainnya hanya mendapat tunjangan pemerintah saja.

Menilik apa yang sudah dilaksanakan di Desa Pekuncen, maka ada beberapa catatan penting berkaitan dengan pelaksanaan kewenangan desa, baik kewenangan (hak) asal usul maupun kewenangan desa sebagai akibat perubahan kebijakan negara terhadap desa maupun perluasan kewenangan desa akibat penugasan yang diberikan oleh pemerintah atas desa (Pusat, Pemerintah Provinsi, dan Pemerintah Kabupaten). Di Desa Pekuncen hak asal usul terkait kuat dengan keberadaan komunitas Bonokeling, yang merupakan cikal bakal lahirnya Desa Pekuncen. Mengingat 90 \% lebih penduduk Pekuncen merupakan keturunan dari Bonokeling, yang merupakan pengikut Islam Blangkon/Kejawen, maka hak asal usul desa juga berasal dari semua aktivitas (sosial, ekonomi, budaya, politik, dan sebagainya) komunitas Bonokeling tersebut. Dengan perubahan kebijakan negara tentang desa, masa berlakunya UU No. 5 Tahun 1979 tentang Pemerintahan Desatelah merubah fungsi pemerintah desa yang awalnya lebih bernuansa sosial-budaya-ekonomi menjadi lebih politis dimana pemerintah desa melaksanakan fungsi-fungsi pemerintahan sebagai kepanjangan tangan pemerintah atasnya (Pusat, Provinsi, dan Kabupaten). Hal ini juga terkait dengan budaya masyarakat yang selalu sendika dawuh atas apapun yang dibuat oleh negara, sebagaimana yang diutarakan oleh Lurah Suwarno. Namun demikian, Desa Pekuncen sampai hari ini tidak pernah kehilangan identitas sosial-budaya-ekonominya dengan tetap memegang teguh adat dalam penyelenggaraan pemerintahan secara 
umum. Terjadi sinergitas antara lembaga adat yanbg dibangun masyarakat dengan lembaga formal pemerintah desa, karena mereka berasal dari sumber yang sama, yaitu komunitas Bonokeling. Dengan demikian sulit memisah antara hak asal usul dengan perluasan kewenangan desa karena hak asal usul menjiwai semua fungsi penyelenggaraan pemerintahan di Desa Pekuncen. Meskipun demikian, Desa Pekuncen tidak bisa disebut sebagai desa adat, karena tatanan pemerintahannya sudah mengadopsi tatanan pemerintahan desa sebagaimana diatur dalam UU yang mengatur tentang desa.

\section{b. Desa Lerep, Kecamatan Ungaran Barat, Kabupaten Semarang}

Dari sejarah keberadaan desa, desa-desa di Kabupaten Semarang termasuk dalam wilayah Keraton Surakarta, yang memberikan kekuasaan pengelolaan desa dengan standar tertentu. Seperti tanah titisara yang diberikan keraton untuk orang-orang miskin yang tidak memiliki tanah, untuk digunakan sebagai tempat tinggal mereka. Tanah pangonan diberikan hak pengelolaan pada penduduk yang tidak memiliki tanah tetapi punya kemampuan untukmengembangkan peternakan kambing misalnya. Tanah sengkeran diberikan hak pengelolaan untuk ditanam komoditi tertentu, yang menjadi kebutuhan utama masyarakat desa, sebagai bagian dari ketahanan dan kemandirian pangan desa. Tanah Norowito diberikan pada penduduk yang bersedia memelihara sarana dan prasarana umum seperti makam, masjid, jalan desa, dsb. Adapun lurah (kepala desa) sak palungguhane (perangkat desa) mendapat tanah palungguh atau bengkok sebagai penghargaan kerajaan atas tugasnya.

Sebenarnya saat pemberlakuan UU No. 9 Tahun 1965 tentang Desa Praja menegaskan bahwa semua tanah yang saat itu merupakan tanah desa menjadi tanah negara yang bisa dipakai secara perorangan, sebagaimana diamanatkan oleh UU PA (Pokok Agraria) tahun 1960. Namun kebijakan tersebut tidak pernah diekskusi, karena pemerintah juga bersikap ambigu, satu sisi ingin menghargai dan menghormati hak asal usul desa, di sisi lain ingin mengatur desa secara sentralistis. Ada contoh, menurut ayah dari LurahSumaryadi ( Kepala Desa Lerep saat ini) ada beberapa lahan di Dusun Mapagan (saat ini menjadi perumahan) awalnya adalah lahan desa yang disebut sebagai bengkok blandong, yang digunakan untuk pengambilan kayu bakar ataupun kayu untuk kebutuhan acara desa seperti merti dusun, bersih desa, dan kegiatan desa lainnya. Dengan demikian, setiap desa pada dasarnya memiliki bondo desa, yang sekarang dimaknai sebagai hak asal usul. 
Dilihat dari uraian tersebut, sebenarnya konsep kemandirian desa atau otonomi desa sudah sangat baik diterapkan saat masa kerajaan. Seorang lurah harus mampu melihat apa kelebihan dan kekurangan desa, sehingga dia bisa mengembangkan sumberdaya desa dengan optimal. Sejak sekitar tahun 1942 sudah terbit pencatatan tanah bondo deso yang mencatat semua tanah palungguh bagi lurah dan pamong desa (kamituwo, bekel, dsb) yang diperbaharui tahun 1960-an. Catatan itulah yang menjadi dasar terhadap hak asal usul desa. Contoh adalah bengkok lurah seluas 6 ha yang terletak di blok Si Geblek Dusun Lerep, seluas 1,45 ha, tadah hujan; di blok Si Kramat Dusun Lerep seluas 2 ha, tadah hujan; di blok Si Klopo Dusun Lerep, seluas 0,9 ha, tadah hujan; di blok Si Kenteng Dusun Keji, seluas 0,2 ha, irigasi 1/2 teknis; di blok Si Muso Dusun Lerep, seluas 0,25 ha, tadah hujan; di blok Si Wungu Dusun Soka, seluas 0,9 ha, irigasi 1/2 teknis; di blok Tegal Gawok Dusun Lorog, seluas 0,7 ha, tadah hujan; di blok Keji Dusun Keji, seluas 0,4 ha, tadah hujan. Melihat uraian tersebut jelas terlihat bahwa bengkok (sebagai sumber ekonomi) pada dasarnya melekat pada status sosial lurah dan para pamong desa (Carik, Jogoboyo, Ulu-ulu, Modin, Bekel, dsb.) Inilah bagian terpenting dari hak asal usul desa, dimana penghargaaan pada status sosial juga setara dengan penghargaan ekonominya.

Pelaksana Penyelenggaraan Pemerintah Desa Lerep Berdasarkan Peraturan Desa Nomor 3 Tahun 2012 Tentang Susunan Organisasi dan Tata Kerja Pemerintahan Desa Lerep, dimana wewenang kepala desa (lurah) identik dengan kewenangan desa mengingat secara adat status lurah melekat di dalamnya fungsi-fungsi yang harus dijalankan sebagai pemimpin sekaligus pengayom masyarakat. Di Desa Lerep, wewenang kepala desa adalah: (a) memimpin penyelenggaraan pemerintahan desa berdasarkan kebijakan yang ditetapkan bersama BPD; (b) mengajukan rancangan peraturan desa; (c) menetapkan peraturan desa yang telah mendapatkan persetujuan dari BPD; (d) menyusun dan mengajukan rancangan peraturan desa mengenai APB desa untuk dibahas dan ditetapkan bersama BPD; (e) membina kehidupan masyarakat desa; (f) membina perekonomian desa; (g) mengkoordinasikan pembangunan desa secara partisipatif; (h) mewakili desanya di dalam dan di luar pengadilan dan dapat menunjuk kuasa hukum untuk mewakilinya sesuai dengan peraturan perUndangUndangan yang berlaku; dan (i) melaksanakan wewenang lain sesuai dengan peraturan perundang-Undangan yang berlaku.Selain itu, Kepala Desa juga memiliki kewajiban : (a) memegang teguh dan mengamalkan Pancasila, melaksanakan UndangUndang Dasar Negara Republik Indonesia Tahun 1945, serta mempertahankan dan 
memilihara keutuhan negara kesatuan Republik Indonesia; (b) meningkatkan kesejahteraan masyarakat; (c) memelihara ketentraman dan ketertiban masyarakat; (d) melaksanakan kehidupan berkoperasi; (e) melaksanakan prinsip tata pemerintah desa yang bersih dan bebas dari korupsi, kolusi dan nepotisme; (f) menjalin hubungan dengan seluruh mitra kerja pemerintah desa; (g) mentaati dan menegakkan seluruh perUndang-Undangan; (h) menyelenggarakan administrasi pemerintah desa yang baik; (i) melaksanakan dan mempertanggungjawabkan pengelolaan keuangan desa; (j) melaksanakan urusan yang menjadi kewenangan desa; (k) mendamaikan perselisihan masyarakat desa; (l) mengembangkan pendapatan masyarakat desa; (m) membina mengayomi, dan melestarikan nilai-nilai sosial budaya dan adat-istiadat; (n) memberdayakan masyarakat dan kelembagaan desa; dan (o) mengembangkan potensi sumber daya alam dan melestarikan lingkungan. Kewenangan dan kewajiban kepala desa tersebut lalu “dibagi” pada perangkat desa yang terdiri dari Sekretaris Desa (carik), kepala dusun (bekel), kepala urusan kemasyarakatan, kepala urusan keuangan, kepala seksi umum, kepala seksi keuangan, kepala urusan pemerintahan, kepala urusan pembangunan, modin, tukang air dan jogoboyo. Jika disimak, antara kewenangan dan kewajiban lurah pada dasarnya menyangkut tentang fungsi yang sangat luas yang harus diemban oleh lurah.

Adapun kewenangan desa lain, yang dilaksankan sampai tahun 2014, masih merupakan implementasi dari UU No. 32 Tahun 2004 tentang Pemerintahan Daerah, khususnya pasal 14 yang ditindaklanjuti melalui Peraturan Pemerintah No. 38 Tahun 2007 tentang Pembagian Urusan Pemerintahan antara Pemerintah, Pemerintahan Daerah Provinsi, dan Pemerintahan Daerah Kabupaten/Kota, pasal 2. Ada tiga belas bidang yang dilaksanakan di desa: pendidikan, kesehatan, pekerjaan umum, perumahan, penataan ruang, perencanaan pembangunan, lingkungan hidup, pertanahan, kependudukan dan catatan sipil, pemberdayaan perempuan dan perlindungan anak, keluarga berencana dan keluarga sejahtera, sosial, ketenagakerjaan, koperasi dan usaha kecil menengah, penanaman modal, kebudayaan dan pariwisata, kepemudaan dan olah raga, kesatuan bangsa dan politik dalam negeri, pemberdayaan masyarakat, kearsipan, komunikasi dan informatika, pertanian dan ketahanan pangan.

Urusan atau kewenangan tersebut dilaksanakan di desa, meski dalam batas-batas tertentu sesuai dengan kapasitas yang dimiliki desa, dan sulit untuk memisahkan dari hak asal usul desa, fungsi-fungsi tersebut saling berkelindan satu sama lain. 
Identifikasi kewenangan desa existing di Desa Lerep menghasilkan beberapa catatan penting. Pertama, dengan posisi Desa Lerep yang lebih dekat dengan pusat Kota Ungaran membuat Desa Lerep lebih cepat mengantisipasi perubahan-perubahan sosial yang terjadi. Kedua, dengan perubahan yang cepat mengakibatkan beban kewenangan desa makin besar, yang mengakibatkan respon desa harus makin kencang mengingat tuntutan pelayanan makin tinggi. Hal ini disebabkan beban-beban pemerintah kabupaten juga mengalir ke desa, yang menyangkut hampir semua bidang pemerintahan yang ada, sebagaimana sudah diuraikan sebelumnya. Ketiga, meski Desa Lerep mengalami perubahan cukup cepat mengingat posisinya yang dekat dengan pusat kota, namun roh desa yang melekat pada hak asal usul desa maupun kewenangan lain yang dijalankan sebagai konsekwensi perubahan kebijakan negara tentang desa tidak mengubah desa yang memiliki otonomi, sebagaimana awal terbentuknya desa. Keempat, Desa Lerep lebih mampu secara administrasi untuk mengidentifikasi kewenangan ataupun fungsi-fungsi yang dijalankan, memilahnya dengan kewenangan kabupaten dan propinsi, yang menjadi dasar bagi pengelolaan keuangan ke depan, mengingat ada beberapa sumber dana yang harus dikelola desa secara mandiri.

\section{c. Desa Trajumas, Kecamatan Kandangserang, Kabupaten Pekalongan}

Berbeda dengan kondisi infratruktur jalan utama desa, kondisi sosial kemasyarakatan Desa Trajumas masih kental dengan suasana 'desa'. Budaya gotong royong dalam setiap kegiatan dan keperluan anggota warga masyarakat masih sangat kental dirasakan. Tanpa dimintai bantuan warga sekitar akan berbondong-bondong membantu salah satu warga yang sedang memiliki hajat, mulai dari membangun rumah, hajatan khitanan, hingga pernikahan. Dalam kegiatan membangun rumah, tidak hanya pada bagian-bagian tertentu (misalnya memasang bubungan rumah) akan tetapi dalam setiap bagian pekerjaan mulai dari penggalian pondasi, pekerjaan dinding, hingga pekerjaan atap warga sekitar akan saling bergotong royong memberikan bantuan secara bergantian. Acara khitanan dan pernikahan salah satu warga menjadi tanggungjawab seluruh warga untuk mensukseskannya. Kaum pria akan bergotong royong mengurusi pekerjaa 'luar' seperti memasang 'tratak' dan membuat panggung, sementara kaum perempuan akan sibuk memasak di dapur. Hal ini berjalan secara otomatis tanpa harus dikoordinir oleh salah satu warga.

Berbeda dengan acara yang 'mengungkapkan kebahagiaan', acara kematian salah satu warga dipimpin oleh seorang pejabat desa yang disebut 'kayim'. Beliaulah yang 
memimpin acara mulai dari memandikan, mengkafani, menshalatkan, hingga mengantarkan si mayit hingga tempat peristirahatan terakhirnya. Sementara itu kegiatan menggali kubur juga dilakukan secara gotong royong tanpa harus ada yang memerintahkan. Sebagian warga yang biasa menggali kubur akan langsung bekerja, meskipun tanpa perintah. Koordinasi dengan pihak keluarga terkait tempat dilakukan sebelum penggalian dimulai.

Meskipun demikian ada adat istiadat budaya yang sudah hilang. Acara selamatan mulai 'nandur' (menanam) dan saat mau memanen hasil pertanian sudah tidak dilakukan lagi. Demikian juga dengan acara 'nyadran' (bersih kuburan) sudah tidak dilakukan. Satu-satunya budaya yang masih terjaga dengan kuat dan menjadi acara seluruh warga yang dilaksanakan secara besar-besaran adalah 'legenonan' (sedekah bumi) dan syawalan. Dua budaya ini tidak hanya masih kuat di Trajumas akan tetapi secara umum di kota dan Kabupaten Pekalongan. Adapun kesenian lokal yang masih berkembang di Desa Trajumas antara lain adalah kesenian rebana, qosidah, kuda lumping, dan kuntulan.

Acara legenonan dilakukan pada bulan Legeno (penanggalan Jawa) atau bulan Dzulqoidah (penanggalan Hijriyah). Acara dilakukan dengan serangkaian upacara adat sedekah bumi dan puncaknya ditutup dengan 'nanggap' wayang kulit semalam suntuk. Sementara itu acara syawalan dilakukan mulai hari kedua saat Hari Raya Idul Fitri. Hari ke-2 hingga ke-7 seluruh warga melanjutkan puasa Ramadhan dengan puasa sunnah selama enam hari setelah jeda dengan syukuran Idul Fitri. Pada hari ke8 lah syukuran Hari Raya Idul Fitri (atau disebut Syawalan) dilaksanakan. Warga sekitar berkumpul disuatu tempat dengan membawa makanan khas Idul Fitri yaitu lontong opor untuk disantap bersama-sama. Setelah itu baru dilanjutkan dengan acara saling bermaafan melalui jabat tangan diantara para penduduk.

Di Desa Trajumas tidak terdapat bengkok, yang biasanya melekat pada status lurah dan pamong desa (carik, jogoboyo, ulu-ulu, kayim, dan seterusnya). Namun demikian, masih ada tanah kas desa, yang pada saat Desa Trajumas memisahkan diri dari desa induk, Sukoharjo, dirubah fungsinya menjadi bengkok kepala desa (sekitar 2 ha) dan pamong desa (15 orang) mendapat masing-masing 0,5 ha sebagai tambahan penghasilan mereka.

Semangat yang mendasari pembentukan Desa Trajumas adalah agar pelayanan masyarakat desa semakin dekat dan pembangunan semakin merata. Hal ini sudah membuahkan hasil yang cukup dirasakan masyarakat. Pelayanan kebutuhan 
administrasi kependudukan (pengurusan kartu keluarga, KTP, ijin menikah, ijin pindah, ijin masuk, pencatatan kematian, dan pencatatan kelahiran) tidak harus lagi ke Balai Desa Sukoharjo yang letakknya kurang lebih 3 km dengan kondisi jalan yang rusak parah. Selain itu alokasi dana pembangunan yang sebelumnya hanya untuk satu desa Sukoharjo dengan bentangan wilayah yang sangat luas, saat ini menjadi 2 sampai 3 kali lebih besar yang dialokasikan untuk tiga desa hasil pemekaran.

Fungsi keberadaan Pemerintahan Desa masih terbatas pada ruang lingkup keadministrasian tersebut. Potensi-potensi yang ada—sebagaimana telah dijelaskan diatas_-belum dipandang sebagai peluang dan modal untuk menjadikan desa mandiri. Pemerintahan Desa masih kesulitan mencari ‘ceruk’ pengembangan sumberdaya yang akan mendorong kemandirian desa.

Hubungan dengan Pemerintah Kecamatan dan Kabupaten tidak bisa secara tegas dipisah. Hal ini dikarenakan hubungan pemerintahan desa dengan pemerintahan kabupaten pasti melalui pemerintahan kecamatan. Jika dipilah-pilah hubungan antara pemerintahan desa dengan pemerintahan diatasnya adalah sebagai berikut: 1) Tugas pembantuan yang diserahkan kepada desa untuk mengurusi administrasi kependudukan dan pertanahan. Tugas ini merupakan tugas utama keberadaan pemerintah desa; 2) Tugas pembantuan dari pemerintah kabupaten untuk mengurusi pembangunan fisik, sosial kelembagaan, budaya, kesehatan, dan olah raga dengan alokasi anggaran yang terangkum dalam ADD. Tugas desa berkaitan sejak dalam penyusunan rencana (RPJMDes, RKPDes, dan APBDes), pengajuan berkas pencairan, distribusi anggaran kepada lembaga-lembaga ditingkat desa, pelaksanaan pembangunan, hingga laporan pertanggungjawaban. Hal yang sama juga berlaku untuk tugas pembantuan yang diberikan oleh Gubernur Jawa Tengah melalui anggaran Bantuan Gubernur; 3) Tugas pembantuan untuk administrasi dan pendistribusian bantuan dari pemerintah pusat (misalnya raskin dan BPJS/KIP); dan 4) Tugas pembantuan untuk mengumpulkan pajak bumi dan bangunan (PBB).

\section{Desain Kewenangan Desa}

Desain ini hanya mencakup kewenangan desa, tidak mencakup kewenangan desa adat, mengingat di Jawa Tengah tidak memiliki desa adat, meski kehidupan sosial budaya masyarakat desa dipengaruhi oleh adat sebagaimana bisa dilihat di Desa Pekuncen, Kecamatan Jatilawang, Kabupaten Banyumas, namun norma-norma sosial tersebut tetaplah tunduk pada norma hukum yang dibuat negara melalui representasi keberadaan pemerintah desa yang ada.Dalam desain ini juga fokus pada kewenangan 
yang didasarkan hak asal usul desa serta kewenangan lokal berskala desa, sebagai cerminan otonomi desa. Adapunkewenangan yang ditugaskan oleh Pemerintah, Pemerintah Daerah Provinsi, atau Pemerintah Daerah Kabupaten/Kota, dan kewenangan lain yang ditugaskan oleh Pemerintah, Pemerintah Daerah Provinsi, atau Pemerintah Daerah Kabupaten/Kota tidak masuk dalam bagian desain.

\section{Matriks Kewenangan Desa yang Berasal dari Hak Asal Usul Desa Berdasarkan UU No. 6 Tahun 2014 tentang Desa dan Peraturan Pelaksananya}

\begin{tabular}{|c|c|c|}
\hline $\begin{array}{c}\text { Undang Undang No. } 6 \\
\text { Tahun } 2014\end{array}$ & $\begin{array}{c}\text { Peraturan Pemerintah } \\
\text { No. } 43 \\
\text { Tahun } 2015 \\
\end{array}$ & $\begin{array}{l}\text { Permendesa No. } 1 \\
\text { Tahun } 2015\end{array}$ \\
\hline $\begin{array}{l}\text { Pasal 18 } \\
\text { - } \text { penyelenggaraan } \\
\text { Pemerintahan Desa, } \\
\text { - } \text { pelaksanaan } \\
\text { Pembangunan Desa, } \\
\text { - pembinaan } \\
\text { kemasyarakatan Desa, } \\
\text { - pemberdayaan } \\
\text { masyarakat Desa } \\
\text { Pasal 19 } \\
\text { Kewenangan } \\
\text { berdasarkan hak asal } \\
\text { usul }\end{array}$ & $\begin{array}{l}\text { Pasal } 34 \\
\text { Kewenangan Desa } \\
\text { berdasarkan hak asal usul } \\
\text { paling sedikit terdiri } \\
\text { atas: } \\
\text { a. sistem organisasi } \\
\text { masyarakat adat; } \\
\text { b. pembinaan } \\
\text { kelembagaan } \\
\text { masyarakat; } \\
\text { c. pembinaan lembaga } \\
\text { dan hukum adat; } \\
\text { d. pengelolaan tanah kas } \\
\text { Desa; dan } \\
\text { e. pengembangan peran } \\
\text { masyarakat Desa. }\end{array}$ & $\begin{array}{l}\text { Pasal } 2 \\
\text { Ruang lingkup kewenangan } \\
\text { berdasarkan hak asal usul Desa antara } \\
\text { lainmeliputi: } \\
\text { a. sistem organisasi perangkat Desa; } \\
\text { b. sistem organisasi masyarakat adat; } \\
\text { c. pembinaan kelembagaan } \\
\text { masyarakat; } \\
\text { d. pembinaan lembaga dan hukum } \\
\text { adat; } \\
\text { e. pengelolaan tanah kas Desa; } \\
\text { f. pengelolaan tanah Desa atau tanah } \\
\text { hak milik Desa yang menggunakan } \\
\text { sebutan setempat; } \\
\text { g. pengelolaan tanah bengkok; } \\
\text { h. pengelolaan tanah pecatu; } \\
\text { i. pengelolaan tanah titisara; dan } \\
\text { j. pengembangan peran masyarakat } \\
\text { Desa. }\end{array}$ \\
\hline
\end{tabular}

Matriks Kewenangan Desa yang Berasal dari Hak Asal Usul Desa

Berdasarkan UU No. 6 Tahun 2014 tentang Desa dan Hak Asal Usul Desa Eksisting

\begin{tabular}{|c|c|}
\hline $\begin{array}{c}\text { Bidang Kewenangan } \\
\text { (UU No. 6/2014 Ps.18 } \\
\text { Ps.19; PP No.43/2015 } \\
\text { Ps 43; Permendesa } \\
\text { No. 1/2015 Ps 2) } \\
\end{array}$ & Hak Asal Usul Desa Ekisisting \\
\hline $\begin{array}{l}\text { Penyelenggaraan } \\
\text { Pemerintahan Desa }\end{array}$ & $\begin{array}{l}\text { 1. Fungsi/kewenangan asal usul Lurah: memimpin, mengayomi, } \\
\text { melayani masyarakat desa, mengembangkan potensi desa. } \\
\text { 2. Fungsi/kewenangan asal usul pamong desa (Carik:membantu } \\
\text { lurah di bidang administrasi dan pencatatan, Bekel:membantu } \\
\text { lurah mengkoordinir wilayah dusun/dukuh, Bayan:membantu } \\
\text { bekel, Modin/Kayim:mengurus orang lahir dan mati, Ulu-ulu: } \\
\text { membantu pengairan persawahan, Jogoboyo: mengurus }\end{array}$ \\
\hline
\end{tabular}




\begin{tabular}{|c|c|}
\hline & $\begin{array}{l}\text { keamanan desa (ronda), Kamituwo: wakil lurah dalam } \\
\text { pemerintah desa, dll) } \\
\text { 3. Struktur organisasi pemerintah desa sesuai nilai tradisi desa: } \\
\text { menyangkut tidak saja lembaga pemerintah desa dengan sebutan } \\
\text { tradisional masing-masing, tetapi juga hubungan antara lurah } \\
\text { dan pamong desa. } \\
\text { 4. Pengelolaan tanah bondo desa: titisara, pangonan, sengkeran, } \\
\text { norowito, palungguh/bengkok, bengkokblandong, dsb. } \\
\text { 5. Pelayanan pada masyarakat berbasis pada fungsi hak asal usul: } \\
\text { ulu-ulu mengurus pertanian desa, jogoboyo memelihara } \\
\text { keamanan desa, modin/kayim melayani kelahiran dan kematian } \\
\text { penduduk desa, dsb. }\end{array}$ \\
\hline $\begin{array}{l}\text { Pelaksanaan } \\
\text { Pembangunan Desa }\end{array}$ & $\begin{array}{l}\text { 6. Rembug desa : rapat tertinggi desa sbg wahana memutuskan hal- } \\
\text { hal substansial menyangkut kepentingan masyarakat desa seperti } \\
\text { merencanakan kegiatan desa dan mengupayakan dana bersama } \\
\text { (swadaya) untuk pembangunan desa } \\
\text { 7. Memelihara aset desa. }\end{array}$ \\
\hline $\begin{array}{l}\text { Pembinaan } \\
\text { kemasyarakatan Desa }\end{array}$ & $\begin{array}{l}\text { 8. Kepala desa sbg hakim perdamaian desa } \\
\text { 9. Modal sosial desa: membangun saling percaya, kerja bersama } \\
\text { untuk tujuan bersama, gotong royong, dll. } \\
\text { 10. Pelestarian nilai-nilai budaya lokal dan adat istiadat desa, serta } \\
\text { menjaga kearifan lokal yang menyangkut seluruh sendi } \\
\text { kehidupan masyarakat desa }\end{array}$ \\
\hline $\begin{array}{l}\text { Pemberdayaan } \\
\text { masyarakat Desa }\end{array}$ & $\begin{array}{l}\text { 11. Pemberdayaan ekonomi: pemanfaatan penuh bondo desa untuk } \\
\text { kemakmuran masyarakat desa, lumbung desa } \\
\text { 12. Pemberdayaan politik: pemilihan lurah secara langsung. }\end{array}$ \\
\hline
\end{tabular}

Matriks Kewenangan Lokal Berskala Desa

Berdasarkan UU No. 6 Tahun 2014 tentang Desa dan Peraturan

Pelaksananya 


\begin{tabular}{|c|c|c|}
\hline $\begin{array}{c}\text { Undang Undang No. } \\
6 \\
\text { Tahun } 2014\end{array}$ & $\begin{array}{c}\text { Peraturan Pemerintah } \\
\text { No. } 43 \text { Tahun } 2015\end{array}$ & $\begin{array}{l}\text { Permendesa No. } 1 \\
\text { Tahun } 2015\end{array}$ \\
\hline $\begin{array}{l}\text { Pasal 18 } \\
\text { - } \text { penyelenggaraan } \\
\text { Pemerintahan Desa, } \\
\text { - pelaksanaan } \\
\text { Pembangunan Desa, } \\
\text { - pembinaan } \\
\text { kemasyarakatan } \\
\text { Desa, } \\
\text { - pemberdayaan } \\
\text { masyarakat Desa } \\
\text { Pasal 19 } \\
\text { - Kewenangan lokal } \\
\text { berskala desa.l }\end{array}$ & $\begin{array}{l}\text { Pasal 34 } \\
\text { Kewenangan lokal } \\
\text { berskala desa paling } \\
\text { sedikit terdiri atas: } \\
\text { a. pengelolaan tambatan } \\
\text { perahu; } \\
\text { b. pengelolaan pasar } \\
\text { Desa; } \\
\text { c. pengelolaan tempat } \\
\text { pemandian umum; } \\
\text { d. pengelolaan jaringan } \\
\text { irigasi; } \\
\text { e. pengelolaan } \\
\text { lingkungan } \\
\text { permukiman } \\
\text { masyarakat Desa; } \\
\text { f. pembinaan kesehatan } \\
\text { masyarakat dan } \\
\text { pengelolaan pos } \\
\text { pelayanan terpadu; } \\
\text { g. pengembangan dan } \\
\text { pembinaan sanggar seni } \\
\text { dan belajar; } \\
\text { h. pengelolaan } \\
\text { perpustakaan Desa dan } \\
\text { taman bacaan; } \\
\text { i. pengelolaan embung } \\
\text { Desa; } \\
\text { j. pengelolaan air } \\
\text { minum berskala Desa; } \\
\text { dan } \\
\text { k. pembuatan jalan } \\
\text { Desa antarpermukiman } \\
\text { ke wilayah pertanian.. }\end{array}$ & 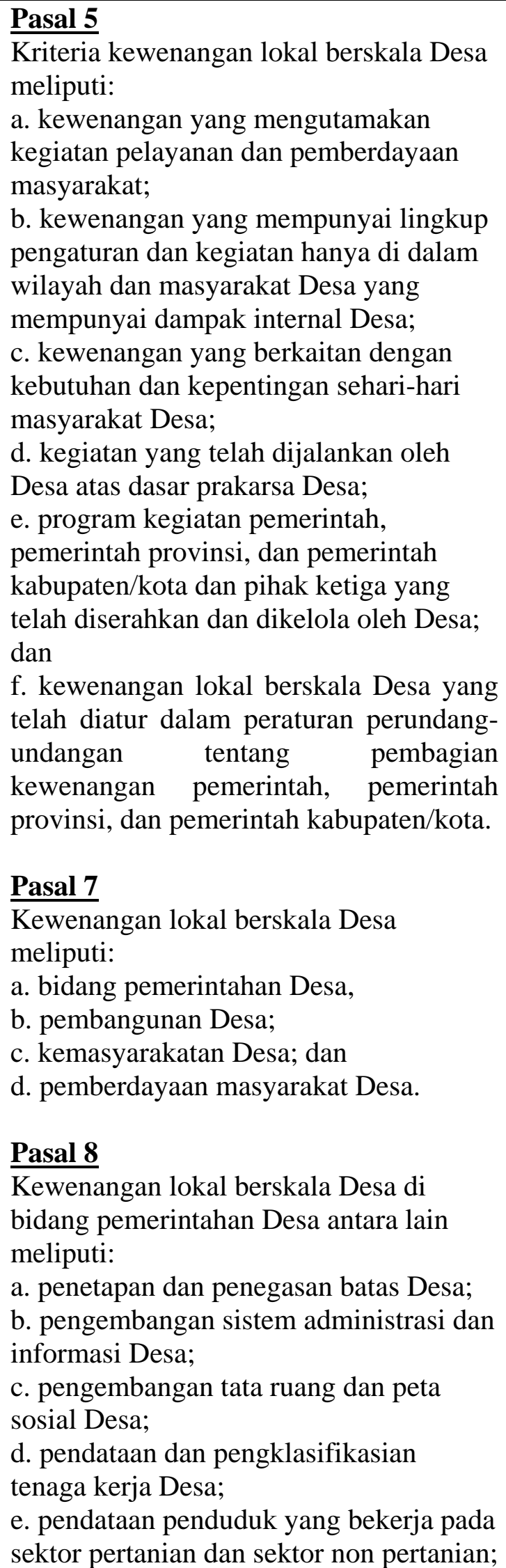 \\
\hline
\end{tabular}




\begin{tabular}{|l|l|}
\hline & f. pendataan penduduk menurut jumlah \\
& penduduk usia kerja, angkatan kerja, \\
pencari kerja, dan tingkat partisipasi \\
angkatan kerja; \\
g. pendataan penduduk berumur 15 tahun \\
ke atas yang bekerja menurut lapangan \\
pekerjaan jenis pekerjaan dan status \\
pekerjaan; \\
h. pendataan penduduk yang bekerja di \\
luar negeri; \\
i. penetapan organisasi Pemerintah Desa; \\
j. pembentukan Badan Permusyaratan \\
Desa; \\
k. penetapan perangkat Desa;
\end{tabular}

Matriks Kewenangan Lokal Berskala Desa

Berdasarkan UU No. 6 Tahun 2014 tentang Desa dan Kewenangan Desa Eksisting

\begin{tabular}{|c|c|}
\hline $\begin{array}{c}\text { Bidang Kewenangan } \\
\text { (UU No. 6/2014 Ps.18 } \\
\text { Ps.19; PP No.43/2015 Ps } \\
\text { 34; Permendesa No. } \\
\text { 1/2015 Ps } 5 \text { Ps.7 ) }\end{array}$ & Kewenangan Lokal Berskala Desa Eksisting \\
\hline $\begin{array}{l}\text { Penyelenggaraan } \\
\text { Pemerintahan Desa }\end{array}$ & $\begin{array}{l}\text { 1. Kependudukan dan catatan sipil: pencatatan, penyedian data, dan } \\
\text { pembuatan surat pengantar kependudukan dan catatan sipil } \\
\text { 2. Ketenagakerjaan: menghimpun dan mencatat data tentang } \\
\text { jumlah penduduk sesuai dengan jenis pekerjaan yang dimiliki, } \\
\text { memfasilitasi modal bagi warga yang berani menciptakan } \\
\text { wirausaha baru, mengikutsertakan pemuda desa untuk ikut } \\
\text { pelatihan-pelatihan produksi dan manajemen usaha. } \\
\text { 3. Kearsipan: penyimpanan dan pengelolaan arsip, utamanya } \\
\text { dokumen-dokumen penting yang berkenaan dengan proses } \\
\text { pengambilan keputusan di desa, dokumen perencanaan } \\
\text { pembangunan, dokumen pelaksananaan pembangunan, dokumen } \\
\text { kepemilikan bondo desa, bengkok, dan lain sebaginya. } \\
\text { 4. Pertanahan dan Penataan ruang: pencatatan terhadap penggunaan } \\
\text { lahan dan pembuatan peraturan desa tentang pemanfaatan ruang }\end{array}$ \\
\hline $\begin{array}{l}\text { Pelaksanaan } \\
\text { Pembangunan Desa }\end{array}$ & $\begin{array}{l}\text { 5. Perencanaan pembangunan: Musrenbangdes (Musyawarah } \\
\text { Rencana Pembangunan Desa), penyusunan Rancangan RKPDes } \\
\text { (Rencana Kerja Pemerintah Desa), penyusunan RKPDes, } \\
\text { penyusunan Rancangan RPJMDes (Rencana Pembangunan } \\
\text { Jangka Menengah Desa), penyusunan RPJMDes, penyusunan } \\
\text { LKPD (Laporan Kinerja Pemerintah Desa), dan penyusunan } \\
\text { LKPJ (Laporan Keterangan Pertanggungjawaban) } \\
\text { 6. Pendidikan: pencatatan data yang berkaitan dengan Angka } \\
\text { Partisipasi Kasar (APK) maupun Angka Partisipasi Murni }\end{array}$ \\
\hline
\end{tabular}




\begin{tabular}{|c|c|}
\hline & $\begin{array}{l}\text { (APM) mulai tingkat Pendidikan Anak Usia Dini (PAUD), } \\
\text { TK/RA, Sekolah Dasar (SD)/MI, SMP/MTs, SMA/SMK. } \\
\text { 7. Kesehatan: pencatatan Angka Harapan Hidup, Angka Kematian } \\
\text { Bayi, Angka Kematian ibu, Angka Kematian Balita, Presentase } \\
\text { balita gizi buruk, Rasio posyandu per satuan balita, rasio } \\
\text { puskesmas, poliklinik, cakupan komplikasi kebidanan yang } \\
\text { ditangani, cakupan balita gizi buruk, cakupan penemuan dan } \\
\text { penangan penyakit (TBC, DBD), cakupan pelayanan kesehatan } \\
\text { rujukan pasien (Jamkesmas, Jamkesda). Mengirim kader utk } \\
\text { pelatihan bidan, peningkatan sarana prasarana di Poliklinik } \\
\text { Kesehatan Desa (PKD), peningkatan manajemen melalui } \\
\text { pembentukan Forum Kesehatan Desa (FKD), menyiapkan } \\
\text { ambulan desa siaga, donor darah siaga (data golongan darah } \\
\text { warga yang siap mendonorkan darahnya kapan saja), informasi } \\
\text { (KB, kesehatan balita, kesehatan ibu hamil, kesehatan lansia), } \\
\text { program jambanisasi, cakupan air bersih. } \\
\text { 8. Pekerjaan umum: pencatatan terhadap jumlah, panjang, kondisi: } \\
\text { jalan, jembatan, saluran dan jaringan irigasi, serta bangunan } \\
\text { bendung, penyediaan air bersih berskala desa } \\
\text { 9. Perumahan: rehab rumah keluarga miskin dan perbaikan } \\
\text { lingkungan. } \\
\text { 10.Pertanian dan ketahanan pangan, } \\
\text { 11.Lingkungan hidup: pembuatan sumur resapan, penanaman } \\
\text { pohon tegakan, penghijauan di sekitar hunian, gerakan bersih } \\
\text { sungai, dan pengelolaan sampah. }\end{array}$ \\
\hline $\begin{array}{c}\text { Bidang Kewenangan } \\
\text { (UU No. 6/2014 Ps.18 } \\
\text { Ps.19; PP No.43/2015 Ps } \\
\text { 34; Permendesa No. } \\
\text { 1/2015 Ps } 5 \text { Ps.7 ) }\end{array}$ & Kewenangan Lokal Berskala Desa Eksisting \\
\hline $\begin{array}{l}\text { Pembinaan } \\
\text { kemasyarakatan Desa, }\end{array}$ & $\begin{array}{l}\text { 12. Kesatuan bangsa dan politik dalam negeri: penyediaan sarana } \\
\text { prasarana keamanan dan ketertiban berupa pos kampling, } \\
\text { ketersediaanp Petugas Linmas desa, melakukan pendekatan } \\
\text { secara khusus dimana terdapat kerawanan sosial. } \\
\text { 13. Komunikasi dan informatika, } \\
\text { 14. Kepemudaan dan olah raga: mengikutsertakan para pemuda di } \\
\text { Karang Taruna dalam berbagai kegiatan desa, seperti proses } \\
\text { pengambilan keputusan, berkesenian, pariwisata, dan olah raga. } \\
\text { 15. Kebudayaan dan pariwisata: pelestarian dan pengembangan } \\
\text { budaya dan seni lokal }\end{array}$ \\
\hline $\begin{array}{l}\text { Pemberdayaan } \\
\text { masyarakat Desa }\end{array}$ & $\begin{array}{l}\text { 16. Pemberdayaan perempuan dan perlindungan anak: PKK dan } \\
\text { Dasa Wisma. } \\
\text { 17. Keluarga berencana dan keluarga sejahtera: pencatatan peserta } \\
\text { KB aktif. }\end{array}$ \\
\hline
\end{tabular}


18.Sosial: pengumpul dan penyalur zakat infaq dan shodaqoh (UPZIS) bedah rumah bagi warga miskin, dan santunan untuk orang lanjut usia yang tidak memiliki keluarga. pencatatan dan penghimpunan data kuantitatif maupun kualitatif Permasalahan Penyandang Masalah Kesejahteraan Sosial (PMKS) tingkat desa

19.Koperasi dan usaha kecil menengah: pencatatan potensi UKM desa, menfasilitasi para pemilik UKM untuk meningkatkan ketrampilan produksi dan manajemen, memberi akses pada UKM untuk pemasaran, mengundang dan menghadirkan pembeli ke UKM, melakukan kerjasama dengan pihak lain untuk meningkatkan mutu dan pemasaran produk.

20.Penanaman modal: manarik investor untuk mengembangkan potensi desa

Desain tersebut bisa berjalan sepanjang pemerintah (pusat, propinsi, kabupaten) taat asas pada asas-asas: rekognisi, subsidiaritas, keberagaman,kebersamaan,kegotongroyongan,kekeluargaan, musyawarah, demokrasi, kemandirian, partisipasi; kesetaraan, pemberdayaan; dan keberlanjutan. Dengan asas rekognisi berarti apapun hasil identifikasi kewenangan desa, baik dari hak asal usul maupun kewenangan lokal berskala desa, harus diakui oleh negara.

\section{Simpulan}

Hasil penelitian ini menunjukkan beberapa simpulan penting. Pertama, secara normatif dengan dua azas utama “rekognisi” dan "subdidiaritas” UU Desa mempunyai semangat perubahan yang mendasar, berbeda dengan azas “desentralisasi” dan "residualitas” yang saat ini masih terasa kuat diterapkan di desa, dimana desa dipandang hanya menjadi bagian dari daerah kabupaten.

Kedua, kombinasi antara azas rekognisi dan subsidiaritas UU Desa menghasilkan definisi desa yang berbeda dengan definisi-definisi sebelumnya. Desa didefinisikan sebagai kesatuan masyarakat hukum yang memiliki batas wilayah yang berwenang untuk mengatur dan mengurus urusan pemerintahan, kepentingan masyarakat setempat berdasarkan prakarsa masyarakat, hak asal usul, dan/atau hak tradisional yang diakui dan dihormati dalam sistem pemerintahan Republik Indonesia.

Ketiga, kewenangan merupakan elemen penting sebagai hak yang dimiliki oleh sebuah desa untuk dapat mengatur rumah tangganya sendiri. Dari pemahaman ini jelas bahwa dalam membahas kewenangan tidak hanya semata-mata memperhatikan kewenangan atau fungsi yang melekat pada kepala desa dan pamong desa, namun juga merambah pada masyarakat desa sebagai sebuah entitas. Dari empat kewenangan 
tersebut, pada dua kewenangan pertama yaitu kewenangan asal usul dan kewenangan lokal berskala desa, terdapat beberapa prinsip penting yang dimiliki desa yaitu diakui dan ditetapkan langsung oleh undang-undang dan dijabarkan oleh peraturan pemerintah.

Keempat, pengamatan terhadap pelaksaaan kewenangan desa eksisting menunjukkan bahwa desa tidak bisa diperlakukan sama sebagaimana memperlakukan daerah kabupaten. Kabupaten disiapkan sebagai pelaksana desentralisasi, yang melaksanakan sebagian kewenangan yang diberikan oleh Pusat. Dengan demikian organisasi pemerintahannya juga didesain untuk melaksnakan kewenangankewenangan yang diberikan pusat tersebut, seperti terbentuknya lembaga Dinas, Badan, maupun Kantor. Desa berbeda, karena memiliki kewenangan yang berasal dari hak asal usul, bukan pemberian dari pusat sebagai bagian dari desentralisasi yang biasa disebut kewenangan residu. Dengan demikian otonomi desa berbeda dengan otonomi daerah. Otonomi desa sudah ada jauh sebelum republik ini berdiri, dan meski didesain ulang berkali-kali melalui kebijakan pusat tentang desa , namun otonomi desa tetep eksis, salah satunya adalah dengan keberadaan wewenang hak asal usul yang melekat pada status sosial kepala desa dan pamong desa , apapun nama dan penyebutannya, serta tercermin dari perilaku masyarakat desa yang menjunjung tinggi kehidupan sosial budayanya.

Kelima, meski hak asal usul masih ada namun diakui bahwa terjadi perubahan struktur ekonomi desa kontemporer yang lebih mendekati industri daripada pertanian. Hal ini menyebabkan urusan-urusan atau kewenangan pemerintahan desa pun mengalami pergeseran dari sektor pertanian ke sektor non pertanian. Kewenangan atau urusan desa yang dikenal dengan hak asal usulpun mengalami perubahan bentuk.

Keenam, desain yang diusulkan adalah memasukkan kewenangan desa eksisting masuk dalam “wadah” yang dikonstruksi UU tentang desa, namun dengan semangat melalui diterapkannya taat azas, dimana pemerintah (pusat dan daerah) merekognisi apapun kewenangan yang saat ini dilaksanakan oleh desa.

\section{E. Saran}

Ada beberapa saran terkait implikasi UU desa terhadap kewenangan desa. Pertama, bahwa pusat memberikan dana desa, itu adalah kewajiban negara untuk memberikan kesejahteraan pada pemerintah dan masyarakat desa, sebagai bagian dari penerapan asas subsidiaritas. Dengan demikian sudah menjadi hak pemerintah dan masyarakat 
desa untuk mendapatkan dana desa, karena menjadi bagian yang tidak terpisahkan dari NKRI. Inilah pengejawantahan dari azas subsidiaritas.

Kedua, jika pusat mau konsisten dengan dua azas di dalam UU, yaitu rekognisi dan subsidiaritas, maka tidak perlu ada peraturan menteri yang mengatur secara rigid tentang kewenangan lokal berskala desa. Beri saja batas waktu agar masing-masing desa mengidentifikasi kewenangannya, lalu pemerintah kabupaten (melalui peraturan daerah) memberikan pengakuan pada kewenangan-kewenangan yang sudah ada.

\section{DAFTAR PUSTAKA}

Ashshofa, Burhan. 2004. Cet. IV. Metode Penelitian Hukum. Jakarta: Rineka Cipta.

Hofsteede, W.F. 1971. Decision-Making in Four West Javanese Villages. Nijmegen: Offsetdrukkerij Faculteit der Wiskunde en Natuurwtwnshappen.

Explorations in Law and Society. New York:Routledge, 1993.

Kartohadikoesoemo, Soetardjo. 1965. Desa. Bandung: Sumur.

Koentjaraningrat. 1989. Pengantar Ilmu Antropologi. Jakarta: Aksara Baru.

Kushandajani. 2008. Otonomi Desa berbasis Modal Sosial, Perspektif Socio-legal. Semarang: Jurusan Ilmu Pemerintahan FISIP Undip.

Luhmann, Niklas. A Sociological Theory of Law. Trans by Elizabeth King. Ed. by Martin Albrow. London: Routledge and Kegan Paul, 1985.

Nasution, S. 1996. Metode Penelitian Naturalistik Kualitatif. Bandung: Transito.

Ridwan, dkk. 2008. Islam Kejawen: Sistem Keyakinan dan Ritual Anak-Cucu Ki

Bonokeling. Purwokerto: STAIN Purwokerto Press dan Unggun Religi.

Surianingrat, Bayu. 1980. Desa dan Kelurahan Menurut UU No. 5/1979, Jakarta: Metro Pos.

Tjiptoherijanto, Prijono dan Yumiko M. Prijono. 1983. Demokrasi di Pedesaan Jawa, Jakarta: Sinar Harapan.

Turkel, Gerald. Law and Society: Critical Approaches. Boston: Allyn \& Bacon, 1996.

Warassih, Esmi. 2005. Pranata Hukum: Sebuah Telaah Sosiologis. Semarang: Suryandaru Utama.

\section{$\underline{\text { Jurnal }}$}

Kushandajani. 2011. "Konstruksi Hukum Pemerintahan Desa: pemikiran Perubahan Kebijakan bagi Desa”. POLITIKA, Jurnal Magister Ilmu Politik UNDIP, Vol. 2, No. 1, April 2011. 
2010. “Makna Otonomi Daerah di Wilayah Laut Bagi Masyarakat Pesisir Kota Semarang”. Jurnal Media Hukum (JMH), FH Universitas Muhammadiyah Yogyakarta, Vol. 17, No. 1, Juni 2010, SK Akreditasi No. 43/Dikti/Kep/2008.

2009. "Dilema Keberadaan Pamong DesaLegal Gap Posisi dan Peran Pamong Desa dalam Konstruksi Hukum dan Sosial”.Yustisia. Universitas Sebelas Maret, Edisi 76 (Januari-April 2009, Tahun XIX),SK Akreditasi No. 43/Dikti/Kep/2008.

Puspawaty, Dian, dkk . "Analisis Pelaksanaan Kewenangan Pemerintahan Desa dalam Bidang Kemasyarakatan di Desa Sumare, Kecamatan Simboro, Kabupaten Mamuju”.Unhas. http://repository.unhas.ac.id/handle/123456789/239. Accessed: 29/03/2014, 22:13.

Rusfiana, Yudi. Penataan urusan desa berdasarkan urusan pemerintah kabupaten yang diserahkan pada desa di Kabupaten Bandung. FISIP Unikom. Jurnal Ilmu Politik dan Komunikasi (Jipsi). Vol. 1. http://jipsi.fisip.unikom.ac.id/jurnal/penataan-urusan-desa.10, Accessed: 29/03/2014, 22:04.

Widyandini, Wita., Atik Suprapti, dan R. Siti Rukayah. 2013. "Pengaruh Sistem Kekerabatan terhadap Pola Perkembangan Permukiman Bonokeling di Banyumas. Jurnal Teodolita, Vol. 14, No. 2, Desember 2013.

\section{Makalah}

Hoessein, Benyamin. "Isu-isu Seputar Desa dalam Kaitannya dengan UU No. 22 Tahun 1999”. Makalah. Disampaikan pada Seminar Terbatas dan Seminar Pluralisme Hukum, Fakultas Hukum UI, 2 Agustus 2000.

\section{Peraturan}

Indonesia, Undang-Undang tentang Desapraja, UU No. 19 tahun 1965, LN No. 84 Tahun 1965, TLN No. 2779.

Indonesia, Undang-Undang tentang Pokok-Pokok Pemerintahan di Daerah, UU No. 5 tahun 1974, LN No. 38 Tahun 1974.

Indonesia, Undang-Undang tentang Pemerintahan Desa, UU No. 5 tahun 1979, LN No. 56 Tahun 1979, TLN No. 3153.

Indonesia, Undang-Undang tentang Pemerintahan Daerah, UU No. 22 tahun 1999, LN No. 60 Tahun 1999, TLN No. 3839.

Indonesia, Undang-Undang tentang Pemerintahan Daerah, UU No. 32 tahun 2004, LN No. 125 Tahun 2004, TLN No. 4437.

Indonesia, Undang-Undang tentang Desa, UU No. 6 tahun 2014, LN No. 7 Tahun 2014, TLN No. 5495. 